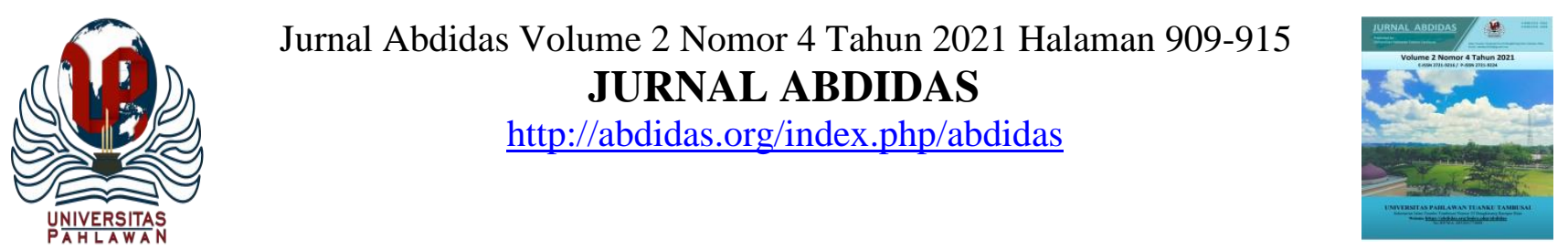

\title{
Pembinaan Kegiatan Pengelolaan dan Pengendalian Sampah di Kota Batam
}

\author{
Ganda Sirait $^{1}$, Arsyad Sumantika ${ }^{2 \varpi}$, Yuli Siyamto ${ }^{3}$ \\ Teknik Industri, Universitas Putera Batam, Indonesia ${ }^{1,2}$ \\ Sistem Informasi, Universitas Putera Batam, Indonesia ${ }^{3}$ \\ E-mail : ganda@puterabatam.ac.id ${ }^{1}$ arsyad.sumantika@ puterabatam.ac.id $^{2}$ yuli.Siyamto@ puterabatam.ac.id ${ }^{3}$
}

\begin{abstract}
Abstrak
Salah satu penyebab kejadian bencana alam seperti banjir akibat dari penanganan pengelolaan sampah yang tidak optimal. Kepedulian masyarakat perlu dibina dalam mengatasi permasalahan yang berkaitan dengan tata kelola sampah. Salah satu permasalahan yang ada di daerah pemukiman adalah berkaitan dengan tata kelola pengelolaan sampah. Berdasarkan hasil pengamatan di Batu Aji, Batam, budaya tata kelola pengelolaan sampah masih belum optimal. Salah satunya adalah kurang adanya pemanfaatan lingkungan berdaya saing dengan cara memanfaatkan pengelolaan sampah menggunakan metode 3R. Metode 3R merupakan bentuk kegiatan yang produktif seperti melakukan kegiatan mengurangi sampah (reduce), menggunakan kembali sampah (reuse) dan mendaur ulang sampah menjadi produk yang bernilai ekonomi/ komersial (recycle). Berdasarkan hasil pelaksanaan pembinaan pengelolaan sampah yang sedang berjalan menggunakan metode 3 $\mathrm{R}$ (Reduce, Reuse, dan Rcycle) di Kelurahan Kibing dapat disimpulkan bahwa pemahaman masyarakat sekitar semakin meningkat setelah diberikan pemaparan materi oleh tim pengabdian masyarakat. Masyarakat cukup antusias untuk melakukan pengelolaan sampah yang lebih baik lagi dan dapat menghasilkan nilai tambah bagi masyarakat sekitar. Kesimpulan lain didapatkan bahwa perlu dilakukan penyuluhan lanjutan misalnya kepada sasaran lain seperti anak-anak agar membiasakan diri pada pemilahan sampah yang baik dan benar dan penyuluhan lanjutan kepada ibu-ibu terkait pemanfaatan nilai ekonomi pengelolaan sampah.
\end{abstract}

Kata kunci : metode 3R, pemukiman masyarakat, pengelolaan sampah

\section{Abstract}

One of the causes of natural disasters such as flooding is the result of improper waste management. Community awareness needs to be fostered in overcoming problems related to waste management. One of the problems in residential areas is related to waste management. Based on observations in Batu Aji, Batam, the culture of waste management is still not optimal. One of them is the lack of competitive environmental utilization by utilizing waste management using the $3 R$ method. The $3 R$ method is a form of productive activity such as reducing waste (reducing), reusing waste and recycling waste into products of economic/commercial value (recycle). Based on the results of the ongoing implementation of waste management development using the $3 R$ (Reduce, Reuse, and Rcycle) method in Kibing Village, it can be concluded that the understanding of the surrounding community is increasing after being given material exposure by the community service team. The community is enthusiastic enough to carry out better waste management and can generate added value for the surrounding community. Another conclusion was that it was necessary to carry out further counseling, for example to other targets such as children in order to familiarize themselves with proper and correct waste sorting and further counseling to mothers regarding the utilization of the economic value of waste management.

Keywords : $3 R$ method, community settlement, waste management

Copyright (c) 2021 Ganda Sirait, Arsyad Sumantika, Yuli Siyamto

$\triangle$ Corresponding author

Address : Universitas Putera Batam

Email : arsyad.sumantika@puterabatam.ac.id

DOI : https://doi.org/10.31004/abdidas.v2i4.395

ISSN 2721- 9224 (Media Cetak)

ISSN 2721- 9216 (Media Online) 
910 Pembinaan Kegiatan Pengelolaan dan Pengendalian Sampah di Kota Batam- Ganda Sirait, Arsyad Sumantika, Yuli Siyamto

DOI: https://doi.org/10.31004/abdidas.v2i4.395

\section{PENDAHULUAN}

Praktik pengelolaan sampah pada setiap daerah memiliki cara yang berbeda misalnya pada negara berkembang praktik pengelolaan sampah masih terbatas hal yang bersifat dasar, berbeda dengan praktik pengelolaan sampah pada negara maju di mana sudah bisa melakukan pengelolaan sampah menjadi suatu output yang bernilai produktif dan barang yang dapat dikomersialkan. Dalam negara berkembang sampah merupakan suatu benda atau bahan yang sudah tidak diperlukan lagi oleh manusia sehingga dibuang. Biasanya semua sampah tersebut menjijikkan dan kotor sehingga harus dibakar atau segera dibuang (Mulasari, 2013).

Terdapat persayaran mengenai pengelolaan sampah, namun dalam tata cara pengelolaan sampah yang terpadu tidak hanya melibatkan kegiatan pengumpulan, pengangkutan, dan pengolahan saja, tetapi juga melibatkan aktivitas pendauran ulang menjadi barang yang memiliki nilai ekonomis. Hal ini karena permasalahan sampah meliputi bagian hilir, proses dan hulu. Pada bagian hilir contohnya pembuangan sampah yang terus meningkat, pada bagian proses contohnya keterbatasaan sumber daya manusia, dan pada bagian hulu contohnya kurang optimalnya sistem yang akan diterapkan pada proses akhir (Mulasari, 2013).

Selain itu terdapat faktor yang menjadi penghambat yang dapat mempengaruhi pengolahan sampah misalnya kepadatan penduduk, sosial ekonomi dan karakteristik lingkungan fisik, sikap, perilaku serta budaya yang ada di masyarakat yang kurang terkontrol (Sahil et al., 2016).

Berdasarkan survei yang dilakukan oleh tim pengabdi masyakakat, di daerah Batu Aji, Batam terdapat banyak timbunan sampah yang tidak terurus. Banyak warga yang belum bisa memanfaatkan sampah tersebut untuk dapat dimanfaatkan kembali seperti di daur ulang atau menghasilkan nilai ekonomi yang bermanfaat. Budaya pengelolaan sampah di warga tersebut masih belum optimal, Salah satu contohnya adalah belum maksimalnya kegiatan pengelolaan sampah dan memanfaatkan sampah ke dalam nilai yang bermanfaat. Belum maksimalnya perencanaan dalam pengolahan sampah tersebut mengakibatkan kurang maksimalnya juga sistem pengolahan sampah (Sari, 2017).

Oleh karena itu, diperlukan suatu metode pemanfaatan lingkungan berdaya saing dengan cara memanfaatkan pengelolaan sampah menggunakan metode 3R. Metode 3R merupakan Metode 3R meliputi suatu kegiatan mengurangi sampah (reduce), menggunakan kembali sampah tersebut ke nilai yang lebih berguna (reuse) dan mendaur ulang sampah menjadi produk yang komersial (recycle).

Salah satu bentuk kegiatan reduce adalah penggunaan kertas dapat digantikan soft file melalui perangkat digital, kegiatan reuse contohnya adalah dengan menggunakan barang plastik kembali atau menggunakan botol minum yang dapat digunakan kembali. Sedangkan contoh kegiatan recycle dibagi menjadi tiga bentuk pengelolaan sampah yaitu organik (basah) dimana sampah dibuat menjadi kompos, anorganik dimana 
911 Pembinaan Kegiatan Pengelolaan dan Pengendalian Sampah di Kota Batam- Ganda Sirait, Arsyad Sumantika, Yuli Siyamto

DOI: https://doi.org/10.31004/abdidas.v2i4.395

sampah dapat dibuat menjadi bentuk kerajinan, dan B3 (Arisona, 2018).

Berdasarkan analisis situasi tersebut, setiap warga harus memahami bahwa tata kelola sampah merupakan hal yang wajib dimengerti dan dilaksanakan sebagai mana mestinya sesuai dengan tanggung jawab warga terhadap lingkungan sekitar. Dukungan dan kesadaran dari pihak warga menjadi hal yang penting dalam keberlangsungan penerapan pengelolaan sampah di lingkungan sekitar. Oleh karena itu, tata kelola sampah khususnya kepada warga Batu Aji, Batam perlu dioptimalkan kembali pelaksanaannya karena kegiatan ini berkaitan dengan strategi dan kebijakan pemerintah mengenai penangan dan tata kelola sampah yang sudah diamanatkan oleh UU mengenai pengelolaan sampah.

\section{METODE}

Kegiatan pengabdian kepada masyarakat dilakukan pada bulan Januari - Juli 2021 yang dibagi menjadi 5 kegiatan utama yang berlokasi pusat di Kelurahan Kibing, Batu Aji, Batam. Pembinaan akan dilaksanakan dalam durasi 4-5 jam selama 5 kali pertemuan yang diberikan kepada pihak warga sekitar.

Kegiatan pengabdian kepada masyarakat dilakukan dengan peserta adalah warga sekitar yang terbagi menjadi 5 bentuk kegiatan dengan mengambil hari minggu dari Januari - Juli 2021. Hari pertama sampai ketiga mencakup materi dasar pemilahan sampah, bahaya, dan manfaat ekonominya, sedangkan pada hari keempat dan kelima berupa penyuluhan tentang metode pengolahan sampah menggunakan metode $3 R$.
Kegiatan 3R (Reduce, Reuse, dan Rcycle) memiliki prinsip utama yang harus diketahui oleh setiap warga negara terkait pengelolaan limbah dan sampah yang optimal yang mencakup 3 prinsip dasar yaitu terkait prinsip pencegahan, prinsip daur ulang dan prinsip pembuangan limbah tanpa adanya daur ulang (Zaman et al., 2017).

\section{HASIL DAN PEMBAHASAN}

Hasil kegiatan pengabdian kepada masyarakat secara mandiri mengenai pengelolaan sampah menggunakan metode $3 \mathrm{R}$ (Reduce, Reuse, dan Rcycle) dilakukan secara bertahap. Tim dosen menyelenggarakan edukasi kepada masyarakat dilakukan secara periodik dan berdasarkan kesepakatan warga. Pada pertemuan tersebut kegiatan pengabdian diadakan minimal 1 bulan sekali pada awal bulan. Nantinya setiap kegiatan akan dilakukan evaluasi terhadap pemahaman masyarakat mengenai penataan dan pengelolaan sampah yang baik dan benar.

Pada pertemuan awal, tim dosen memberikan edukasi pengolahan sampah dan cara pemanfaatannya. Edukasi pada tahap awal berupa sosialisasi awal, kemudian setelah itu pada pertemuan berikutnya atau yang kedua tim dosen memberikan pengarahan dan sharing ilmu mengenai pengelolaan sampah seperti pemahaman terhadap pengetahuan umum peserta tentang sampah dan permasalahannya. Kemudian pada pertemuan ketiga tim pengabdi masyarakat melanjutkan pembinaan dengan melakukan penyuluhan mengenai pemahaman terhadap pengetahuan masyarakat terhadap jenis-jenis sampah dan penataan sampah yang baik dan benar. 
912 Pembinaan Kegiatan Pengelolaan dan Pengendalian Sampah di Kota Batam- Ganda Sirait, Arsyad Sumantika, Yuli Siyamto

DOI: https://doi.org/10.31004/abdidas.v2i4.395

Pada pertemuan keempat tim pengabdi masyarakat memberikan seperangkat sarana dan prasarana berupa tong sampah untuk menampung sampah kering dan basah serta tempah sampah khusus dalam pemilahan menggunakan metode 3R. Tong sampah dan tempat sampah khusus $3 \mathrm{R}$ tersebut dapat digunakan oleh setiap warga dalam memilah sampah sesuai keperuntukannya sehingga diharapkan tiap warga dapat memilah jenis sampah yang baik dan benar. Tempat pengolahan sampah tersebut, misalnya berupa penyediaan tong sampah dan tempat sampah khusus $3 \mathrm{R}$ sangat perlu diadakan karena memiliki dampak positif bagi masyarakat (Nurlaela, 2017).

Kemudian pada pertemuan 5 dilakukan evaluasi kegiatan tim pengabdi masyarakat dengan perwakilan kelurahan. Hasil evaluasi adalah perlu dilanjutkan pengabdian karena banyak warga yang masih belum konsisten mengenai pemilahan sampah sehingga perlu dilakukan pendampingan secara berkelanjutan melalui sistem door to door atau kegiatan terbuka. Evaluasi lain juga berupa permintaan warga mengenai pelatihan agar sampah yang dihasilkan dapat menghasilkan manfaat secara nilai ekonomi dengan memanfaatkan pemilahan sampah kering dan basah, serta adanya demo secara berkelanjutan mengenai implementasi pengelolaan sampah menggunakan metode 3R agar tiap rumah tangga memiliki tambahan penghasilan dari pengelolaan sampah dan konsisten terhadap budaya memilah, memilih, mengurangi, dan memanfaatkan menjadi komoditas ekonomi.

Pada kegiatan tersebut sasaran dibatasi untuk masyarakat pada lingkungan masyarakat di sekitar Kelurahan Kibing dengan metode social distance. Metode ini dilakukan dengan tatap muka, namun terdapat batasan masyarakat yang boleh menghadiri kegiatan, hanya beberapa warga yang dapat hadir pada kegiatan ini. Edukasi dilakukan dengan memberikan pengetahuan baru terhadap masyarakat di mana saat dilakukan edukasi, partisipasi masyarakatnya terhadap pengelolaan sampah selama ini hanya kegiatan kumpul angkut dan buang saja, dan belum masuk kedalam pemilahan sampah organik dan non organik. Kegiatan implementasi pengelolaan sampah menggunakan metode $3 R$ juga belum familiar oleh masyarakat sekitar.

Adapun target yang ingin dicapai oleh tim pengadian masyarakat ini adalah sebagai berikut:

1. Tim memperkenalkan pengetahuan dasar tentang sampah, seperti jenis dan macam sampah yang beredar (dapat dimanfaatkan maupun yang tidak dapat dimanfaatkan kembali atau berbahaya) dan edukasi terhadap kebijakan yang ada serta kondisi pengelolaan sampah saat ini.

2. Tim dapat memberikan pengarahan tentang tentang dasar pengelolaan sampah menggunakan metode $3 \mathrm{R}$.

3. Warga lingkungan sekitar pengabdian dapat mengevaluasi kondisi lingkungan masyarakat sebelum maupun setelah penerapan pengelolaan sampah.

4. Warga masyarakat dapat menemukan ide baru berupa penciptaan nilai ekonomi berupa penciptaan kegiatan kewirausahaan berdasarkan konsep 3R pada lingkungan sekitar. 
913 Pembinaan Kegiatan Pengelolaan dan Pengendalian Sampah di Kota Batam- Ganda Sirait, Arsyad Sumantika, Yuli Siyamto

DOI: https://doi.org/10.31004/abdidas.v2i4.395

5. Mengajak para warga dan pihak yang terkait di lingkungan sekitar untuk menerapkan sejak dini mengenai pengelolaan sampah supaya memiliki kepedulian yang lebih pada lingkungan sekitar.

Berdasarkan kegiatan pengabdian yang sudah dilakukan, secara keseluruhan kegiatan pengabdian berjalan dengan lancar dan informasi mengenai pengelolaan sampah yang baik dan benar tersampaikan sesuai dengan sasaran kegiatan. Sasaran tersebut juga didasarkan pada kebutuhan warga mengenai informasi bagaimana cara mengolah sampah menjadi sesuatu yang bernilai. Namun pelaksanaan pengabdian ini juga tidak luput dari kendala yang dihadapi, yakni sebagai berikut :

1. Adanya virus corona yang menyebabkan pembinaan tidak dilakukan secara ramai melalui kegiatan banyak partisipasi masyarakat, namun dilakukan oleh perwakilan warga saja untuk menghindari kerumunan.

2. Keterbatasan dana dari tim pengabdi masyarakat terkait dengan pembelian sejumlah perlengkapan pengelolaan sampah, seperti tong sampah kering, tong sampah basah, tempat sampah khusus untuk penanganan sampah $3 \mathrm{R}$ dan peralatan lainnya yang mendukung kegiatan.

3. Perlu kebiasaan dan keinginan kuat dari masyarakat supaya budaya pengelolaan sampah yang baik dan benar dapat diterapkan secara konsisten.

Oleh karena itu, tim pengabdi masyarakat dengan adanya kendala yang terjadi di lapangan memiliki komitmen bersama dengan para pihak warga sekitar sekitar, yakni sebagai berikut :

1. Pembinaan melalui metode door to door berdasarkan hasil kesepakatan tim pengabdian masyarakat dengan perangkat kelurahan, bahwa tiap warga perlu dilakukan pendampingan khusus supaya warga sadar dan terbiasa dalam pengelolaan sampah.

2. Pembinaan melalui praktik berupa pendaur ulangan sampah (recycle) menjadi produk yang bernilai jual. Sebagai contohnya adalah sampah kertas, kemasan plastik mie instan, sabun, minyak dapat dibuat menjadi produk kerajinan.

3. Pembinaan kegiatan dengan cara memanfaatkan sampah organik dapat dibuat kompos dan digunakan sebagai penyubur tanaman maupun penghijauan, sehingga sampah yang berada di sekitar lingkungan yang dapat dimanfaatkan semaksimal mungkin.

4. Berdasarkan hasil diskusi dengan perangkat desa perlu dilakukan penyuluhan lanjutan kepada anak-anak agar membiasakan diri pada pemilahan sampah yang baik dan benar dan penyuluhan lanjutan kepada ibu-ibu terkait pemanfaatan nilai ekonomi pengelolaan sampah.

Berdasarkan hasil kegiatan tersebut, pada masa yang akan datang perlu dilakukan kembali edukasi dan pendampingan secara rutin agar masyarakat dapat membiasakan diri mengelola sampah yang baik dan benar. Hal ini dikarenakan dalam membangun kesadaran masyarakat 
914 Pembinaan Kegiatan Pengelolaan dan Pengendalian Sampah di Kota Batam- Ganda Sirait, Arsyad Sumantika, Yuli Siyamto

DOI: https://doi.org/10.31004/abdidas.v2i4.395

mengenai pengelolaan sampah yang baik dan benar tidak semudah membalikkan telapak tangan, karena dibutuhkan adanya kerja sama dari semua pihak, baik masyarakat, pemerintah maupun pihak ketiga sebagai pendukung (Rizal, 2011).

Oleh karena itu setelah pelaksanaan pembinaan oleh tim pengabdi masyarakat, diharapkan warga dapat mewujudkan lingkungan sekitar yang asri, tidak terjadi penumpukan sampah, terhindar dari penyakit yang berasal dari tumpukan sampah dan dapat menjadi kebiasaan yang baik untuk selalu peduli dalam menjaga kebersihan lingkungan sekitar, dan dapat menciptakan ide wirausaha dari pemahaman mengenai pengelolaan sampah berbasis $3 R$.

Output yang diharapkan dari pemberian bekal pengetahuan tentang pengelolaan sampah 3R adalah dapat mengingkatkan efektifitas pembelajaran yang baik dengan memperhatikan aspek lingkungan dan adanya ide kegiatan kewirausahaan terutama di daerah Batam sehingga lingkungan sekitar tersebut tersebut secara tidak langsung dapat membantu pemerintah dalam melakukan pengelolaan dan pemanfaatan sampah sesuai pedoman yang telah ditetapkan oleh pemerintah. Kemudian dapat secara langsung membantu lingkungan sekitar menjadi lebih asri dan terbebas dari timbulnya penyakit yang berasal dari pengelolaan sampah yang tidak baik, serta dapat menciptakan nilai tambah bagi masyarakat.

\section{SIMPULAN}

Berdasarkan hasil pelaksanaan pembinaan pengelolaan sampah menggunakan metode 3R (Reduce, Reuse, dan Rcycle) di Batu Aji, Batam dapat disimpulkan bahwa pemahaman masyarakat sekitar semakin meningkat setelah diberikan pemaparan materi oleh tim pengabdian masyarakat. Masyarakat cukup antusias untuk melakukan pengelolaan sampah yang lebih baik lagi agar kebiasaan pengelolaan sampah dapat berjalan secara konsisten di masa yang akan datang. Oleh karena itu, tim pengabdi masyarakat harus melakukan pendampingan secara continue agar kesadaran warga meningkat dan melakukan pendampingan pada kegiatan pengabdian selanjutnya yang lebih berfokus pada pemanfaatan nilai ekonomi daerah.

Selain itu, terdapat beberapa saran perbaikan agar progam pengabdian masyarakat ini memiliki dampak positif bagi masyarakat sekitar yaitu perlu dilakukan kegiatan lanjutan untuk mengelola sampah, terutama sampah yang sering ditemukan yaitu sampah dapur yang belum terolah (sampah anorganik) selama ini menjadi barang/ produk yang bermanfaat dan bernilai ekonomi, misalnya dengan memberikan pelatihan pembuatan barang/ produk kerajinan dari sampah anorganik dapur/ rumah tangga sehingga memberikan nilai ekonomi daerah sekitar.

\section{UCAPAN TERIMA KASIH}

Ucapan terima kasih disampaikan kepada pihak Kelurahan Kibing, Batu Aji, Batam yang sudah memberikan kepercayaan kepada para tim pengabdi masyarakat sebagai narasumber kegiatan yang diadakan secara periodik sesuai dengan perencanaan kegiatan yang tersusun. 
915 Pembinaan Kegiatan Pengelolaan dan Pengendalian Sampah di Kota Batam- Ganda Sirait, Arsyad Sumantika, Yuli Siyamto

DOI: https://doi.org/10.31004/abdidas.v2i4.395

\section{DAFTAR PUSTAKA}

Arisona, R. D. (2018). Al Ulya: Jurnal Pendidikan Islam. 3, 39-51.

Mulasari, S. A. (2013). Hubungan Tingkat Pengetahuan Dan Sikap Terhadap Perilaku Masyarakat Dalam Mengolah Sampah Di Dusun Padukuhan Desa Sidokarto Kecamatan Godean Kabupaten Sleman Yogyakarta. Jurnal Kesehatan Masyarakat (Journal of Public Health), 6(3). https://doi.org/10.12928/kesmas.v6i3.1055

Nurlaela. (2017). Dampak Keberadaan Tempat Pengolahan Sampah 3R (Reduce, Reuse, recycle) Viva Mas Terhadap Lingkungan Sosial Ekonomi Masyarakat di Kelurahan Bumbu Apus Kecamatan Pamulang Kota Tangerang Selatan.

Rizal, M. (2011). ANALISIS PENGELOLAAN PERSAMPAHAN PERKOTAAN (Sudi kasus pada Kelurahan Boya Kecamatan Banawa Kabupaten Donggala). Smartek, 9, 155-172.

Sahil, J., Muhdar, M. H. I. Al, Rohman, F., \& Syamsuri, I. (2016). Sistem Pengelolaan dan Upaya Penanggulangan Sampah Di Kelurahan Dufa-Dufa Kota Ternate. Jurnal Bioedukasi, 4(2), 478-487.

Sari, N. S. (2017). Analisis Pengelolaan Sampah Padat Di Kecamatan Banuhampu Kabupaten Agam. Jurnal Kesehatan Masyarakat Andalas, $\quad 10(2), \quad 157$. https://doi.org/10.24893/jkma.v10i2.201

Zaman, B., Oktiawan, W., Hadiwidodo, M., Sutrisno, E., \& Purwono. (2017). Desentralisasi pengolahan limbah padat rumah tangga menggunakan teknologi biodrying tidak dikelola dengan baik. Metode pengolahan limbah padat ( sampah) dengan menghindari dampak negatif pada lingkungan seperti bau dan polusi emisi, pencegahan . Prinsi. 1(3), 18-24. 